\title{
Symfonia smutku - Valse Mélancolique Olhy Kobylańskiej
}

\author{
Abstract \\ Symphony of Sadness - Olha Kobylianska's Novella Valse Mélancolique
}

The article is a proposition of interpretation Valse Mélancolique - short stories written by the Ukrainian women writer Olha Kobylianska (1863-1942). This is an example of literary research devoted to synthetic overview of the phenomenon of insanity / mental illness in Ukrainian Modernism literature (late nineteenth and early twentieth century). Insanity, being one of the main themes of modernist literature, today does not live to see a proper discussion in the Ukrainian literary studies. The resulting so far work has moved this issue only into a selective and fragmentary way, always on the margins of the main range of research interests, thus far definitely without exhausting problem. Madness constituted for Kobylianska one of the most important and dramatic forms of exclusion, hence the belief that the mentally ill is not so much a sick man, as enslaved, subjected to the pressure of power, deprived of the right to subjectivity, of their own forms of existence.

Keywords: Olha Kobylianska, melancholia, sadness, music

Słowa kluczowe: Olha Kobylańska, melancholia, smutek, muzyka

Ponure, nienasycone pragnienie rządzi mną, a dusza moja nie ma już sił, choć niczego nie stworzyła. Tylko męczyła się i obijała o jakiś mur, otaczający mój świat. Chciałabym czegoś... nie wiem dokładnie, czego... co by mnie satysfakcjonowało, albo co uczyniłoby mnie silną, potężną!

Olha Kobylańska, Carówna²

1 Artykuł jest fragmentem rozdziału obronionej w 2017 roku rozprawy doktorskiej Sygnatury choroby - literatura defektu w ukraińskim modernizmie (Eesia Ukrainka, Olha Kobylańska, Wotodymyr Wynnyczenko, Mykoła Kulisz). Publikacja powstała przy wsparciu finansowym Narodowego Centrum Nauki w ramach stypendium doktorskiego na podstawie decyzji numer DEC-2014/12/T/HS2/00141.

2 О. Кобилянська, Царівна [w:] eadem, Твори у 5 m., т. 1, Київ 1963, s. 116. 
Melancholia kończy się na asymbolii, na utracie sensu; jeśli nie jestem w stanie już dalej tłumaczyć albo metaforyzować, zamykam usta i umieram.

Julia Kristeva, Czarne stońce ${ }^{3}$

Z różnorodnych konstruktów literackich, mieszczących się na wspólnej dla afektu i defektu płaszczyźnie, takich jak mania (z radości), melancholia/depresja (smutek), anoreksja (wstręt), antyspołeczne zaburzenia osobowości (złość) czy zaburzenia lękowe, w tym fobie (strach), przedmiotem namysłu chcę uczynić melancholię i jej literackie realizacje. W humanistycznej refleksji, ale też w zapisach ludzkich doświadczeń melancholia posiada inny status niż większość fenomenów z pola afektywności i defektywności. Wytwory kultury, będąc zapisem doświadczenia utraty, są potwierdzeniem faktu, że melancholia jest podstawowym budulcem cywilizacji i elementem paradygmatu nowoczesności.

W twórczości ukraińskich autorek końca XIX wieku badacze odnajdują klimat epoki i różne tendencje związane z procesem literackim i kulturowym fin de siècle'u:

Koniec XIX - początek XX stulecia na Ukrainie zapewnił unikatowe połączenie wielowektorowych tendencji. Czas ten można nazwać okresem intensywnych poszukiwań - swojego pochodzenia, własnego państwa, siebie, a zarazem okresem „rozszczepienia” osobowości jako jednostki twórczej, znalezienia wewnętrznych, psychologicznych czynników wywołujących dramatyczne sprzeczności. (...) twórczość ta kładzie mocne akcenty na problemach ludzkiego jestestwa, wyboru etyczno-moralnego, rozdwojenia, granicznego doświadczenia, sytuacji egzystencjalnej, podświadomości ${ }^{4}$.

Nie powinno dziwić zatem, że modernistki, unowocześniając proces literacki, wprowadzają do prozy i dramatów nowy typ bohaterki, oddając jej pogłębiony psychologicznie obraz jako portret zdominowanej przez defekt świadomości. Wira Ahejewa wnioskuje, że w utworach realizujących wówczas temat melancholii (kulturowego fenomenu od wieków wypełnianego treścią) chodzi „o historię kształtowania się nowej kobiety, o bolesne wychodzenie z patriarchalnych struktur i odnalezienie własnej tożsamości"5. Tamara Hundorowa wskazuje natomiast postać kobiety melancholiczki jako jeden z literackich typów kobiecości, w którym odzwierciedla się narodowy charakter: ,smutny nastrój Ukraińców, melancholijność ukraińskich pieśni, zarażenie niemocą w życiu społecznym i psychicznym oraz wyraźne poczucie kryzysu płci (szczególnie męskiej)”“.

3 J. Kristeva, Czarne stońce. Depresja i melancholia, tłum. M.P. Markowski, R. Ryziński, Kraków 2007, s. 48.

4 Л.В. Томчук, Жіноча меланхолія як текст, „Наукові записки. Національного університету Острозька академія. Серія Філологічна" 2008, nr 9, s. 464.

5 В. Агеєва, Жіночий простір. Феміністичний дискурс украӥнсько го модернізму, Київ 2003, s. 157.

6 Т. Гундорова, Femina Melancholica. Стать і культура в тендерній утопії Ольги Кобилянської, Київ 2002, s. 146. 
Sam termin „melancholia”7 ewoluował od greckiego melaine koina - synonimu „czarnej żółci”, odsyłającego do teorii czterech płynów, do choroby psychicznej objawiającej się jako depresja. Przez wieki zastępowano pojęcie melancholii innymi - zbanalizowanymi lub specjalistycznymi - określeniami: smutek, lypemania, monomania smutna. Zachowujący od starożytności ciągłość termin „melancholia” zastąpiono w dziewiętnastowiecznych ujęciach psychiatrycznych i późniejszych klasyfikacjach medycznych nazwami poszczególnych jednostek chorobowych, m.in. pojęciem depresji. Oczywiście trudno postawić znak równości między melancholią, zwłaszcza z jej bogatą tradycją starożytną i sensami, jakimi obrosła, a depresją jako jednostką chorobową. Chcę jedynie zaznaczyć, że właśnie pod koniec XIX wieku zaistniał ów moment przejścia od metafory „czarnej żółci” i mitu ,wpływu Saturna” ku psychofizjologicznym i neurobiologicznym próbom rozpatrywania smutku jako choroby. A połączenie afektu i defektu w melancholii rejestrowane było w literaturze patograficznej wyjątkowego typu w swoistych pamiętnikach cierpienia, zapiskach stanów smutnych, na kartach bólu, gdzie pisano o własnych doświadczeniach emocjonalnych i gdzie tworzono literackie reprezentacje smutku.

Nastroje rozpaczy i figury melancholii pojawiają się w wielu utworach Olhy Kobylańskiej ${ }^{8}$, szczególnie analizujących przestrzenie kobiecej psychiki na tle inercji świata końca XIX wieku. Tekstem, który przedstawia wizerunek tej kulturowej figury choroby, jest opowiadanie Kobylańskiej Valse Mélancolique ${ }^{9}$ (Melancholijny walc, 1897), opisujące przyjaźń trzech młodych, inteligentnych, niezależnych i bardzo różnych kobiet. Marta, Hanna i Sofia reprezentują postawy emancypantek, artystek (malarka Hanna, pianistka Sofia), ale też kobiet pragnących stabilizacji w roli matki i żony (kształcąca się na nauczycielkę Marta) ${ }^{10}$ :

Muzyczna polifonia wdziera się do świata artystycznego noweli, tworząc jej melancholijną tonalność, fabułę i kompozycję. Motyw walca wszechobecny w utworze staje się motywem przewodnim, a na jego tle rzeźbione są trzy typy kobiet, połączonych poszukiwaniami piękna i głęboko zindywidualizowane ${ }^{11}$.

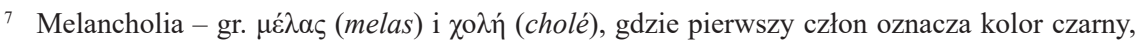
ciemny, a także przymiotniki: przygnębiający, ponury, posępny, niezrozumiały czy enigmatyczny; człon drugi oznacza żótć, ale także gniew, oburzenie, gorycz, żal, przykrość, rozgoryczenie. Zob. R. Kilbansky, E. Panofsky, F. Saxl, Saturn i melancholia. Studia z historii, filozofii, przyrody, medycyny, religii oraz sztuki, tłum. A. Kryczyńska, Kraków 2009, s. 36.

8 Zob. rozdział „Людина”: O sancta hysteria! [w:] Т. Гундорова, Femina Melancholica..., s. $95-103$.

9 Utwór pierwotnie napisany w języku niemieckim w 1894 r., po ukraińsku wydany w $1898 \mathrm{r}$. w „Літературно-науковий вісник”. Cytaty według wydania О. Кобилянська, Valse Mélancolique, [w:] 3 неприкритою головою. Украӥнська жіноча проза, упоряд. В. Агаєва, Комора, Київ 2013, c. $11-50$.

10 O kobiecej przyjaźni w utworach Kobylańskiej i Wilde w kontekście modeli stosunków opisanych w tekstach Virginii Woolf i rozpoznań genderowych o literaturze przełomu XIX i XX wieku autorstwa Elaine Showalter zob. В. Агеєва, Жіноча дружба, [w:] eadem, Жіночий простір..., s. $198-218$.

11 М. Ткачук, Творчий портрет Ольги Кобилянської, „Наукові записки. Тернопільський національний педагогічний університет ім. В. Гнатюка. Серія: Літературознавство” 2010, nr 29, s. 34. 
Autorka większość swoich utworów poświęciła prezentowaniu postaci kobiet, tworzeniu portretów nowej bohaterki, analizie społecznych mechanizmów, które determinowały losy członkiń małych społeczności (wiejskich) czy oddawały ograniczenia mieszczaństwa ${ }^{12}$. Uznać można Kobylańską za główną przedstawicielkę ruchu emancypacyjnego na Bukowinie, również dzięki jej działalności w Towarzystwie Ruskich Kobiet na Bukowinie ${ }^{13}$. Pisarka tak charakteryzuje główne postaci słowami Marty - narratorki i bohaterki:

Mieszkamy razem we trzy. W tej chwili jedynie we dwie. Jedna malarka i ja. (...) Miała dwadzieścia kilka lat, była zniemczoną Polką i traktowała swoje życie bardzo poważnie. Drażliwa i humorzasta, kiedy malowała, w codziennym życiu była człowiekiem najmilszym. (...) Das schönste Glückskind ${ }^{14}$. (...) Ja chciałam być nauczycielką. Uczyłam się muzyki, języków i przeróżnych ręcznych robótek, ba - i wszystko inne, co tylko można było, zbierałam w sobie, gromadziłam niczym kapitał ${ }^{15}$.

Bohaterki Valse Mélancolique wpisują się w autorski, feministyczny sposób budowania kobiecego podmiotu - kształcą się, rozwijają swoje pasje, mają silną potrzebę niezależności i wolności (wolnomyślicielka Hanna, dziewczyna o artystycznej duszy, ,w sztuce poważna i głęboka niczym morze"16) lub pragną prawdziwego partnerskiego związku z mężczyzną (Marta o ,nieartystycznym mieszczańskim rozumie" ${ }^{17}$ ):

(...) nie będziemy, na przykład, żonami swoich mężów albo matkami, będziemy jedynie kobietami. Rozumiesz? Będziemy ludźmi, którzy nie stali się ani żonami, ani matkami, a rozwinęli się tak w pełni ${ }^{18}$.

Rozmowy między bohaterkami i próby autocharakterystyk dopełniają wizerunku świadomych swojej wyjątkowości jednostek, wierzących w brak ograniczeń i żyjących w swoistym ménage à trois. Autorka tworzy nie tyle zbiorowy portret młodych kobiet, ile kilka różnorodnych portretów kobiecych pragnień działania, chęci zmiany, wiary w możliwość samostanowienia. „Kobiece dążenie do aktywności, ulubionej pracy w zwyczajnych okolicznościach, nie może zrealizować się w niczym innym prócz nostalgii i znużenia" ${ }^{19}$ - pisze Ahejewa o bohaterkach prozy Kobylańskiej i zwraca uwagę, że w tekstach bukowińskiej

12 Takie bohaterki Kobylańska opisuje na przykład w powieściach Людина (Ljudyna; Człowiek, 1886), Царівна (Cariwna; Carówna, 1895). O bohaterkach kobiecych w prozie Kobylańskiej zob. Т. Гундорова, Ольга Кобилянська contra Ніцщее, або Народження жінки з духу природи [w:] Гендер і культура. Збірник статей, упоряд. В. Агеєва, С. Оксамитна, Факт, Київ 2001, s. 34-52; Т. Гундорова, Femina melancholica.... Z kolei kobiece szaleństwo analizuje Kobylańska w powieściach Земля (Zemlja; Ziemia, 1895-1901) czy w В неділю рано зілля копала (W пеdiljи rano zillja kopała; W niedzielę rano ziele kopała, 1908).

13 О. Рибак, Украӥнский жіночий рух у контексті теоріі соиіализму і націоналного відродження (кінець XIX - початок XX cm.) [w:] Ukrainska myśl polityczna w XX wieku, red. M. Pułaski, Kraków 1993, s. 71.

14 Wspaniałą ulubienicą losu (niem.).

15 О. Кобилянська, Valse Mélancolique ..., s. 12.

16 Ibid., s. 25.

17 Ibid., s. 14.

18 Ibid.

19 В. Агеєва, Жіночий простір..., s. 181. 
autorki kobiety po raz pierwszy w ukraińskiej literaturze przemówiły z taką różnorodnością o ,innych namiętnościach”.

W feministycznych poglądach Kobylańskiej odzwierciedlają się filozoficzne idee Friedricha Nietzschego, które wpłynęły na uformowanie się światopoglądu skoncentrowanego wokół figury silnej, niezależnej kobiety jako pełnoprawnej uczestniczki kultury. W usta malarki Hanny autorka wkłada słowa będące ideową deklaracją człowieka końca XIX wieku:

Gdyby wszyscy byli oświeconymi i wychowanymi artystami, począwszy od uczuć aż po strój, nie byłoby tyle zła na świecie, jak teraz, tylko sama harmonia i piękno. A tak? Co wokół nas? Tylko my sami podtrzymujemy piękno w świcie, my, artyści, wybrana garstka społeczeństwa, rozumiesz? $?^{20}$

Mimo iż w ukraińskiej kulturze końca XIX wieku dominowały jeszcze tendencje utylitarne z ducha i narodnickie, to już we wczesnej twórczości Kobylańskiej odnaleźć można zapowiedzi modernistycznych haseł sztuki dla sztuki i wyzwolenia człowieka z wszelkich ról (rozwijane w późniejszych tekstach). W wypowiedziach Hanny pobrzmiewają echa Nietzscheańskiej filozofii i modernistycznej wiary w wyjątkowość artysty. Śmiało deklarowana odmienność i postulowana inność nowej kobiety ${ }^{21}$, pragnącej wyzwolić się z ograniczeń ówczesnego społeczeństwa, nie zawsze akceptowanej przez otoczenie, rodzi wyobcowanie i poczucie głębokiego smutku. Jako jeden z najważniejszych elementów inspirujących ukraiński modernizm Sołomija Pawłyczko wskazuje prace niemieckiego filozofa, którego ogłasza inspiratorem ruchu opartego na filozofii pesymizmu, dekadentyzmie czy krytyce mieszczańskiej moralności:

O Nietzschem stopniowo zaczynają mówić niemal wszyscy, ale wiedza o jego ideach nie była głęboka. Większość jego myśli była nie do przyjęcia dla demokratów-narodników (...) a popularność - tymczasowa ${ }^{22}$.

Elementem łączącym twórczość ukraińskiej pisarki i autora Tako rzecze Zaratustra były rozważania na temat samotności, nadczłowieka i moralności:

Poprzez samotność Kobylańska akcentuje indywidualizm swoich bohaterów. Tworzy $\mathrm{z}$ tego pewnego rodzaju kult i podkreśla w ten sposób ich indywidualność i nieprzeciętność. Pozwala to poznać wewnętrzny świat jej bohaterów, ich pragnienia, marzenia, a przez to ich samych. Bohaterowie jej utworów pragną być nietzscheańskimi nadludźmi i osiągnąć swój szczytny cel, do którego zmierzają. Chcą sami dla siebie być celem i wyznaczać swą drogę w życiu. Zaczynają swe działanie od wielkich zadań i mimo niełatwej drogi, uparcie pną się ku górze. To silne indywidualności walczące o swą mocną pozycję społeczną. Przemierzają tzw. wielkie południe, pokonują trudną drogę, aby stać się prawdziwymi nadludźmi. Nietsche także utożsamiał wielkich ludzi z nadludźmi. Jego nadczłowiek miał być istotą

20 О. Кобилянська, Valse Mélancolique..., s. 13.

21 „Jeżeli pozostaniemy kobietami niezamężnymi - mówiła (słów «stara panna» nienawidziła), wtedy też będziemy razem mieszkać. Weźmiemy sobie do towarzystwa jeszcze trzecią osobę, bo dwie to za mało i nie można żadnego programu ani statutu ułożyć, i będziemy żyć. (...) Potem niech nachodzą na nas te upiory, jakimi straszą przed niezamężnością - samotność, brak pomocy, dziwactwo i inne. Nie będziemy śmieszne, nie będziemy - jak mówią - biedne”. Zob. О. Кобилянська, Valse Mélancolique..., s. 13-14.

22 С. Павличко, Дискурс модернізму в українській літературі, Либідь, Київ 1999, s. 46-47. 
silną, obdarzoną wielką mocą, jednostką twórczą, której każda chwila życia jest doskonała i warta ponownego przeżycia. Podobnie jak bohaterowie Kobylańskiej, nietzscheański nadczłowiek żyje ponad zasadami obowiązującymi innych ludzi ${ }^{23}$.

Taką „wybraną istotą” pozwalającą sobie na ustanawianie własnych zasad jest Hanusia, która decyduje się na życie wolnej artystki, nie zważając na społeczne konwenanse i znaczenie statusu zamężnej kobiety.

Sielanka kobiecej przyjaźni i spokojnego oddawania się swoim pasjom została zagrożona przez czynniki ekonomiczne - właściciel wynajmowanego mieszkania podwyższył czynsz i bohaterki były zmuszone albo więcej zarabiać na udzielaniu korepetycji z francuskiego lub angielskiego, albo przyjąć pod swój dach trzecią współlokatorkę. Zapowiedziało ją przeczucie Marty, której w wyobraźni zamajaczył obraz: ,jakieś dziewczęce oblicze, zmarniałe, ze smutnymi oczyma, w jednej chwili wstrząsnął mną jakiś dziwny smutek, niby poczucie niewypowiedzianego żalu, delikatnie, przelotnie" ${ }^{24}$. W końcu pojawia się ta postać ze smutnymi oczyma - Sofia Doroszenko, zdecydowanie najciekawsza bohaterka tego krótkiego prozatorskiego utworu - młoda dziewczyna o złamanym sercu, przygotowująca się do wyjazdu do wiedeńskiego konserwatorium, pobierająca lekcje muzyki w grupie, do której uczęszcza też Marta. Wprowadza się ze swoim czarnym, błyszczącym fortepianem. Cała przesiąknięta jest smutkiem - stroni od ludzi, siedzi w ciemności, pogrążona w apatii patrzy przed siebie:

Widziałam tylko jej ciemne, łagodnie pobłyskujące ciemne włosy, upięte starannie w gruby węzeł i dwukrotnie obwiązaną ciemną wstążką głowę oraz twarz z profilu. Profil miała naprawdę zupełnie klasyczny. Czoło i nos tworzyły jedną miękką linię (...). Spadziste ramiona nadawały jej cechy pewnej pańskości i pewności (...). Nie wiedzieć czemu, bezustannie na nią patrzyłam. Coś mnie do niej przyciągało, jakby usiłowało oddać jej na usługi całą istotę albo nawet więcej: oddać całą jasność swojej duszy, natchnąć ją tym. (...) Wzbudzała sympatię i zaufanie. Jakąś łagodnością, pewnością, a najbardziej - swoim spojrzeniem. Spokojnym, a zarazem pełnym melancholiii ${ }^{25}$.

Melancholia jako romantyczny i modernistyczny konstrukt kulturowy opisywana była głównie w kontekście braku, pustki, straty, ale także przesytu, dystansu, znużenia, anhedonii. Ponadto romantyczne rozumienie tego fenomenu oscylowało wokół pojęć geniuszu i twórczości. Akcentowano jej aspekt filozoficzny (egzystencjalny) - traktując po heideggerowsku jako rozumienie bytu (bytu świata i bytu człowieka), psychologiczny - pojmując melancholię jako niebezpieczną nadwrażliwość i delikatność struktury psychiki ludzkiej. Próbowano wreszcie zrekonstruować jej modernistyczne oraz ponowoczesne odmiany, a także opisać fenomen melancholicznej estetyki czy wręcz écriture melancolique. Melancholia jest konstruktem, który jawi się jako wspólny teren pól medycyny (Antoni Kępiński), filozofii, kultury, literatury. Figurze tej poświęcono wiele miejsca w dys-

23 A. Waga, Niektóre aspekty intertekstualności w utworach Olgi Kobylańskiej, „Науковий вісник Волинського національного університету імені Лесі Українки” 2009, nr 12, s. 46. Na temat nietzscheanizmu w twórczości Kobylańskiej zob. też М. Павлишин, Ольга Кобилянська: прочитання, Акта, Харків 2008.

24 О. Кобилянська, Valse Mélancolique..., s. 18.

25 Ibid., s. 22-27. 
kursie nauk humanistycznych. Marek Bieńczyk określa ją jako ,rozproszenie powodowane przez uporczywe roztrząsanie straty"26, jako ,bezkresne rozpamiętywanie w świecie, który nie przestaje się przeobrażać" 27 i powołuje się na definicję Gérarda de Nervala, który postrzega melancholię jako „chorobę widzenia rzeczy, jakimi są"28. Søren Kierkegaard na pytanie, czym jest melancholia, odpowiada: ,jest to histeria ducha" ${ }^{29}$. Sigmund Freud natomiast pisze: „,kto urodził się melancholikiem, sączy smutek z każdego wydarzenia" "30.

Tworząc postać Sofii Doroszenko, kobiety o artystycznych upodobaniach, przepojonej smutkiem i tęsknotą, Kobylańska wprowadza do ukraińskiej literatury figurę melancholiczki, która ,reprezentuje osobowość naznaczoną samotnością i w pewnym stopniu straumatyzowaną niespełnioną miłością, zdradą mężczyzny, a także przywiązaniem do matki" ${ }^{31}$. Takie postaci czyni Kobylańska bohaterkami innych swoich utworów, m.in. w opowiadaniu Yac (Czas, 1895), zbiorze prozatorskim Через кладку (Czerez kładku; Przez kładke, 1905), w autobiograficznej powieści napisanej po niemiecku Гортенза (Hortenza; Hortensja, 1880), czy w powieściach Людина (Ljudyna; Człowiek, 1886), Царівна (Cariwna; Carówna, 1895), Нiоба (Nioba; Niobe, 1905), wyznaczając w ten sposób silną linię literatury defektywnej tożsamości. Pietro Citati pisał o figurze melancholika:

Podczas gdy inni kroczą po linii prostej przyzwoitej egzystencji albo żyją w bezpiecznym kręgu, doświadczając wszystkiego z umiarem, on zna zasadę, brak równowagi, nadmiar: niekończące się cierpienie, nadludzkie szczęście, rozpaczliwy chłód, absolutną ciemność, całkowitą jasność. Prawda potrzebuje takiego braku umiaru ${ }^{32}$.

Poczucie apatii mogło wynikać z uświadomienia sobie braku możliwości wpływu na faktyczną zmianę sytuacji, mogło być przejmowane z zewnątrz - ze świata pogrążonego w kryzysie, oddawać defektywny nastrój podmiotu. Melancholia przejawia się w muzyce ${ }^{33}$, w smutnych tonach staje się „budulcem” pogrążonej w zadumie duszy, w którą tony „leją się jedną wielką strugą smutku"34. Sofia Doroszenko zwierza się swoim towarzyszkom:

Fach mój jest wymagający i żąda dla siebie niczym nieograniczonej wolności. A ponieważ przywykłam swobodnie oddawać muzyce uczucia, to zajmowałby moją duszę wieczny niepokój i podejrzenie, że rozstrajam nerwy innym i źle wpływam na otoczenie, a tego bym nie chciała!... Potrzebuję spokoju wypływającego z zamiłowania do muzyki i harmonii w re-

26 M. Bieńczyk, Melancholia. O tych, co nigdy nie odnajda straty, Warszawa 2012, s. 13.

27 Ibid.

28 Ibid., s. 14.

29 S. Kierkegaard, Albo-albo, t. 2, thum. K. Toeplitz, Warszawa 1982, s. 253.

30 S. Freud, cyt. za: M. Bieńczyk, op. cit., s. 15.

31 Т. Гундорова, Femina melancholica..., s. 138.

32 P. Citati, Saturn i melancholia, tłum. J. Ugniewska, „Odra” 2003, nr 10, s. 38.

33 O wpływie muzyki na twórczość Olhy Kobylańskiej zob. jej teksty autobiograficzne: О. Кобилянська, Слова зворушеного серия: Щоденники. Автобіографії. Листи. Статті та спогади, упорядн. Ф.П. Погребенник, Дніпро, Київ 1982 oraz Ю. Микосянчик, Театр і музика в житті Ольги Кобилянської, „Буковинський журнал” 1998, nr 1, s. 33-43.

34 О. Кобилянська, Valse Mélancolique..., s. 11. 
lacjach, przede wszystkim - harmonii! (...) Tu oczywiście panuje zamiłowanie do piękna, ale ja potrzebuję melomanów ${ }^{35}$.

Co wieczór Sofia grała dla swoich przyjaciółek kompozycje - zawsze jeden wybrany utwór, bezustannie go powielając, grała tak przejmująco, że ,dusza była w stanie zrozumieć smutek"36. Dźwięki napływające jedne po drugim, słabsze i mocniejsze, wypełniały przestrzeń zanurzonego w mroku pokoju - ,powtarzając, przemieniały się niezauważenie w piękno"37. Ten gest powtórzenia wprowadza melancholię na wyższy poziom:

Melancholia jest bowiem tą postawą egzystencjalną, w której najpełniej wyraża się monotonia istnienia oddanego bez reszty ciężarowi, nuda tożsamości, powagi, głębi, pamięci wszystkich tych modi egzystencjalnych, które opierają się na wytrwałym i sumiennym, zamkniętym w sobie powtórzeniu ${ }^{38}$.

Historię każdej epoki można pokazać przez metaforę choroby, która w danym czasie zdominowała wyobraźnię ludzi, budząc w nich lęk i zainteresowanie (trąd w średniowieczu, gruźlica i syfilis w XIX, AIDS pod koniec XX wieku). Konkretna zagrażająca jednostka nozologiczna zdyskursywizowana w literaturze i sztuce wpływała na kulturowy klimat epoki, społeczne relacje, a epoka nadawała chorobie konkretne sensy. Jednym z takich fenomenów jest melancholia obrosła w różnorodne znaczenia, skonceptualizowana w tekstach kultury, figura XIX-wiecznej tożsamości. W tym wypadku oddająca uczucia i lęki ,nowej kobiety", wyzwalająca ją z roli histeryczki i czyniąca pełnoprawną uczestniczką kulturowej historii smutku. Jak zauważa Lubow Tomczuk:

kobiety odbierały przejściową sytuację w sposób „nastrojowy”, wyznaczając jej ducha oraz ogólny ton. Obserwowały przewagę smutnych nastrojów, co zabarwiało tę epokę i było swoistym tłem dla twórczości artystycznej ${ }^{39}$.

Sofia pogrążona jest w żałobie po śmierci ojca, który z powodu kłopotów finansowych i zmartwień zmarł nagle w jej ramionach, a choroba matki przykutej do wózka i mieszkającej z bratem pogłębia jej tęsknotę. Julia Kristeva opisuje różnice między męskim a kobiecym poczuciem straty, opierając rozpoznania na temat tego drugiego jako silnie związanego z relacją z matką ${ }^{40}$ (i niepodlegającego ukojeniu czy przepracowaniu). Podobnie w teoriach Luce Irigaray - kobiecy podmiot oderwany od matki traci tożsamość (,to je wykorzenia z tożsamości i podmiotowości" ${ }^{41}$ ). Bohaterka odchorowała także nieszczęśliwą miłość i wzgardzone przez wybranka uczucia. W tym Marta i Hanna widzą przyczynę zbytniej nerwowości i melancholii swojej przyjaciółki:

35 Ibid., s. 27.

36 Ibid., s. 30 .

37 Ibid.

38 A. Bielik-Robson, Inna nowoczesność. Pytania o współczesna formułę duchowości, Kraków 2000, s. 63.

39 Л.В. Томчук, ор. cit., s. 465.

40 Zob. B. Smoleń, Koncepcja melancholii Julii Kristevej [w:] Sumienie, wina, melancholia. Materiały polsko-niemieckiego seminarium, red. P. Dybel, Warszawa 1999, s. 224-225.

41 L. Irigaray, Ciało w ciało z matka, tłum. A. Araszkiewicz, Kraków 2000, s. 21. 
Uśmiech na jej ustach, pojawiający się nadzwyczaj rzadko, był jakby odwiecznie przygaszony smutkiem. (...) Z zamiłowań Sofii wywodzę naturę delikatną, w pewnym sensie dbałą o piękno i sztukę. A z drugiej strony - jest dla mnie zagadką. Obojętna na wszystko jak drzewo. (...) Zawsze spokojna jak marmur. „Muzyka” - jak ją nieraz nazywałyśmy zaczynała uważnie przyglądać się swoim dłoniom, jakby dostrzegała na nich plamy, wstawała i niby zauważywszy na swojej sukni coś do zaszycia, opuszczała powoli głośny pokój. (...) było w niej coś, co wymagało delikatności w myślach i zachowaniu względem niej i to ograniczało ich (innych ludzi - I.B.) wolność... ${ }^{42}$

Defektywna tożsamość bohaterki naznaczona jest melancholią i znajduje wyraz w „muzyce nerwów”43, w której Sofia szuka harmonii (utopijne pragnienie) i spokoju duszy. Chodzi bowiem o najbardziej podstawową figurę egzystencjalną, jedną z głównych idei nowoczesności. W momentach głębokiego smutku i kryzysu Doroszenko siada do instrumentu i gra umieszczoną w tytule opowiadania autorską kompozycję - ,gamy boleści i niespokojne czary w niskich tonach"44 _ Valse Mélancolique:

Był zmierzch i grała z pamięci.

Zaczęła z lekka, z wdziękiem, nielicznymi tonami jakiegoś walca.

Pierwsza część była wesoła, zgrabna i elegancka.

Druga się zmieniła.

Zaczęło się jakieś grzebanie wśród dźwięków, niepokój, rozpaczliwy niepokój! Zatrzymywała się raz po raz na basowych tonach, to niższych, to wyższych, a następnie porzucała je, po czym przechodziła poprzez szaleńczo dynamiczną bolesną gamę w wyższe rewiry. Stąd ponownie zbiegała z płaczem do basów i znów to grzebanie, pełne rozpaczy i niepokoju... wszystko od nowa, i raz jeszcze szereg dźwięków w głąb...

Wesoła harmonia zniknęła; pozostał sam szalony ból, uderzający w szalone zmysły, przerywany jaśniejszymi dźwiękami, niczym chwilowym śmiechem. Grała ponad półgodziny, a potem urwała właśnie w samym środku gamy, która przelatywała ku wyższym dźwiękom, akordem rozdzierającego smutku.

Księżyc świecił i oświetlał całą ścianę pokoju oraz miejsce, gdzie siedziała... ${ }^{45}$

Defektywność aktywizuje w podmiocie ,inny” język do wyrażenia doświadczenia (w tym wypadku dźwięku muzyki), które również jest ,repetytywne i monotonne", jak mowa melancholika, o której pisała Kristeva w Czarnym słońcu:

Przypomnijcie sobie mowę człowieka w depresji; repetytywną i monotonną. Nie można jej związać, zdania rwą się, wyczerpują, zatrzymują. Nie da się sformułować żadnej syntagmy. Powtarzający się rytm i monotonna melodia zaczynają panować w poprzerywanych sekwencjach logicznych i zamieniają je w powtarzające się obsesyjne litanie. W końcu, z chwilą gdy nawet ta skąpa płynność wyczerpie się, czy też po prostu nie zdoła osiąść ze względu na siłę ciszy, melancholik wydaje się cicho zawieszać proces ideacji, mroczniejąc w pustce asymbolii czy też w nadmiarze nieuporządkowanego chaosu ideacji ${ }^{46}$.

42 О. Кобилянська, Valse Mélancolique...., s. 35.

43 Ibid., s. 33.

44 Ibid., s. 37.

45 Ibid., s. 36-37.

46 J. Kristeva, op. cit., s. 39. 
W grze na fortepianie Doroszenko podejmuje próbę rozszyfrowania smutku (elementu własnej tożsamości), pozwala sobie na metaforyczne wysłowienie melancholii i powtarzalne wyrażenie neurozy.

Kobiecy melancholijny podmiot z utworów Kobylańskiej może być interpretowany również jako figura artysty - nadwrażliwego, widzącego więcej odmieńca, odczuwającego samotność w nierozumiejącym go społeczeństwie. Postrzegając melancholię jako pewnego rodzaju świadomość, rodzaj wrażliwości czy strukturę rozumienia ${ }^{47}$, dookreślić można:

Nowoczesna melancholia była opisywana dość jednoznacznie w kategoriach pustki, braku, znużenia, przesytu, niezaangażowania, dystansu, niemocy - jak w romantyzmie i jego, według Mario Praza, dopełnieniu wczesnomodernistycznym. Miała ona charakter wyraźnie egzystencjalny, psychologiczny i indywidualny ${ }^{48}$.

Taki obraz fenomenu odnaleźć możemy w twórczości Kobylańskiej. Przy czym pustka i odczuwalny brak nie są w tej „,muzycznej noweli” zapełniane przez dźwięki, lecz - podkreślane. Smutna muzyka tworzy portret melancholijnej duszy, czyni żal słyszalnym. Gra na fortepianie jest próbą pracy żałoby.

- To walc, Sofie? - zapytałam nieśmiało.

- Walc.

- Piękny...

- Tak! To Valse Mélancolique.

- Czyja kompozycja?

- Moja.

- Masz ją w nutach?

$-\mathrm{Nie}, \mathrm{w}$ duszy... ${ }^{49}$

Czarny fortepian, z którego rezonowały smutne dźwięki walca, jest symbolem, który dołączyć może do innych metaforycznych określeń depresji/melancholii, takich jak: czarna żółć, czarne słońce, znak Saturna. Tamara Hundorowa pisze nawet o fetyszyzacji rezonatora ${ }^{50}$, której dokonuje Doroszenko względem swojego czarnego instrumentu: „mogę całą duszę oddać rezonatorowi. I oddaję. Kiedy siadam do niego, odnajduję równowagę duszy, wraca do mnie duma i poczucie, że stoję wyprostowana!" ${ }^{1}$. Możliwość artystycznej działalności posiada dla bohaterki także terapeutyczną funkcję - pozwala zapomnieć o miłosnym zawodzie.

Nie wiem... po prostu dusza u mężczyzny rozrywała się w piersi przy tych dźwiękach, pełnych gracji, zapowiadających największe szczęście, a zakończonych smutkiem i rozdzierającym niepokojem! To szperanie tam, w niskich tonach, przechodzenie, buszowanie wśród dźwięków w poszukiwaniu czegoś... być może szczęścia? - i na próżno! Urywała nieoczekiwanie $\mathrm{w}$ środku gamy smutnym akordem, pozostawiając w duszy masę uczuć wystawionych jak gdyby na pośmiewisko... ${ }^{52}$

47 M. Dąbrowski, Ponowoczesna melancholia. Modelowanie rozumienia, „Anthropos” 2007, nr 8-9, s. 12.

48 Ibid.

49 О. Кобилянська, Valse Mélancolique..., s. 37.

50 Т. Гундорова, Femina melancholica..., s. 147-151.

51 О. Кобилянська, Valse Mélancolique..., s. 35.

52 Ibid., s. 42. 
Valse Mélancolique towarzyszy bohaterce w trudnych momentach życia, stanowi muzyczne ujęcie smutku i emocji związanych ze zdradą i stratą. Powraca, gdy Sofia widzi swojego ukochanego z małżonką, gdy dowiaduje się o pogarszającym się stanie zdrowia matki, gdy wraca z jej pogrzebu i kiedy dzieje się rzecz najgorsza z możliwych - wuj przesyła telegram, że nie może finansować jej studiów w wiedeńskim konserwatorium. „Alegoria powstała wokół straty, wokół utraty sensu, należy więc do samego sedna estetyki melancholii" ${ }^{53}$ - pisze Bieńczyk. W obliczu owej straty rozlegają się dźwięki melancholijnego walca:

Grała tam, w nieoświetlonym pokoju, a drzwi, podobnie jak na początku, były otwarte... Grała swojego walca, lecz tak, jak nigdy przedtem.

Bodaj nigdy wcześniej nie zasługiwał on na nazwę Valse Mélancolique tak jak teraz. Pierwsza część - niezwykle wesoła i pełna wdzięku, niczym zaproszenie do tańca, a druga... O, ta gama! Ta dobrze nam znana niespokojna gama! Przelatywała szalonym lotem od jasnych dźwięków do głębokich, a tam - niepokój, szperanie, raz za razem rozpaczliwe wygrzebywanie, roztapianie się tonów, bój i znowu zejście dźwięków w dolinę... a potem właśnie w samym środku gamy smutny wieńczący akord.

Hanusia płakała. I ja płakałam.

Wiedziałyśmy obie, że jedno życie zostało złamane.

A potem skończyła grać i weszła ${ }^{54}$.

Chwilę po ostatnim wykonaniu pęka struna fortepianu - moment ten symbolizuje koniec życia bohaterki, która słysząc rozdzierający serce dźwięk, pada omdlała na fortepian i umiera na zawał: „muzyka pozbawiła ją życia... Zabiła ją jedną cieniutką struną" ${ }^{55}$. Różnorodne stany psychiczne i nastroje smutku są w przypadku Sofii w pewnym stopniu również odbiciem zewnętrznych czynników - tęsknota za utraconym uczuciem, wzgardzona miłość, najbliżsi i ukochani, którzy odeszli. Na figurę tę składa się cała gama defektywnych tonów, różnych odcieni nostalgii, smutku, poczucia osamotnienia. Pawłyczko wśród dyskursów określających ukraiński modernizm opisuje także „dyskurs irracjonalnego”, ujmując to odejście od racjonalności jako neoromantyczną cechę. Również w utworach Olgi Kobylańskiej odnajdujemy nieracjonalne elementy, rozważanie fundamentalnych ontologicznych kwestii związanych z intuicją, wśród których autorka Dyskursu modernizmu stawia pytanie następujące: „Czy życie jest racjonalnym czy nieracjonalnym, nie zależy od człowieka, który niezdolny jest nie tylko do kontrolowania istnienia, ale i swoich własnych czynów i uczuć?"56. Prócz szczególnej ,uduchowionej” atmosfery, swoistego artyzmu czy liryzmu prezentowanego w utworach Kobylańskiej, a także pogłębionych portretów psychologicznych kobiecych postaci, irracjonalne elementy pogłębiają tragizm losu bohaterek.

Melancholia jako temat i wartość estetyczna może być łączona z pragnieniem piszących kobiet, by stać się pełnoprawnymi uczestniczkami literackiego procesu, zaś femina melancholica to ,,inny wariant autoprezentacji nowej kobiety, który

\footnotetext{
53 M. Bieńczyk, op. cit., s. 86.

54 О. Кобилянська, Valse Mélancolique..., s. 48.

Ibid., s. 50.

56 С. Павличко, dz. cyt., s. 218.
} 
przypomniał o sobie wraz z typami femme fatale i mannish woman pod koniec XIX i na początku XX wieku" ${ }^{57}$.

W postaci Sofii Doroszenko odnaleźć można figurę melancholiczki opisaną przez Sigmunda Freuda, który w Melancholii i żałobie zaprezentował obniżenie nastroju jako nieprzepracowaną żałobę ${ }^{58}$ po utraconym obiekcie miłości. Strata poniesiona przez bohaterkę nie dotyczy tylko ukochanego, odnosić się może również do śmierci ojca, choroby matki, utraty rodzinnego domu, poczucia stabilizacji, przynależności i bezpieczeństwa, a także wolności samostanowienia o swoim losie. Następstwem tych elementów są: powolna utrata siebie, rozczarowanie, obniżenie nastroju, zwątpienie, apatia i brak sił życiowych. Nieco szerzej interpretuje koncept melancholii w utworach Kobylańskiej Hundorowa:

Melancholijny stan bohaterek Kobylańskiej w pewnym sensie staje się atrybutem procesu modernizacji Ukrainy, która ulega erotyzacji i feminizacji w twórczości Olhy Kobylańskiej. Smutek i melancholia świadczą o upadku narodnickiej idealizacji narodu, etnosu, przeszłości. A melancholia dowodzi istnienia momentu utraty związku z matczynym ciałem narodu, rodziny, ziemi ${ }^{59}$.

Badaczka podkreśla, że ten fenomen kulturowy służy Kobylańskiej do odmalowania utraty ojczyzny, ale też tak ważnego w krajach rolniczych związku z ziemią. Według Freuda konsekwencją utraty ukochanego obiektu lub ideału/ abstrakcji (np. ojczyzny) jest żałoba, w której dochodzi do zubożenia libido i w konsekwencji do rozpadu ,ja" ${ }^{90}$.

Inne koncepcje melancholii to kobiecocentryczne rozpoznania badaczek feministycznych - Irigaray czy Kristevej, w których strata nie musi dotyczyć utraconego obiektu miłości, może nie posiadać desygnatu. Irigaray twierdzi nawet, że to właśnie męski podmiot zdolny jest do melancholii, ponieważ posiada silne superego, czego podmiot kobiecy - melancholiczka nie ma (brak jej ,instynktu narcystycznego" ${ }^{61}$ ). Niemożność dookreślenia i wskazania utraconego obiektu umiejscawia melancholijną defektywność kobiecego podmiotu poza językiem. W procesie żałoby Doroszenko próbuje sobie poradzić z ową niewyrażalnością straty poprzez muzykę. W noweli Olgi Kobylańskiej, opisującej losy trzech typów kobiet, w przypadku melancholiczki Sofii dążenie do wolności (zarówno osobistej, jak i artystycznej) doprowadza do połączenia muzyki i smutku.

57 Т. Гундорова, Femina melancholica..., s. 227.

58 Zob. U. Chowaniec, Melancholia [w:] Encyklopedia gender. Płeć w kulturze, red. M. Rudaś-Grodzka i in., Warszawa 2014, s. 300-302.

59 Т. Гундорова, Femina melancholica..., s. 147.

60 S. Freud, Żałoba i melancholia, tłum. R. Reszke [w:] idem, Psychologia nieświadomości, Warszawa 2007, s. 140-145.

${ }_{61}$ U. Chowaniec, op. cit., s. 301. 


\section{Bibliografia}

Агеєва В., Жіночий простір. Феміністичний дискурс українсько го модернізму, Київ 2003.

Bielik-Robson A., Inna nowoczesność. Pytania o współczesna formułę duchowości, Kraków 2000.

Bieńczyk M., Melancholia. O tych, co nigdy nie odnajda straty, Warszawa 2012.

Chowaniec U., Melancholia [w:] Encyklopedia gender. Płeć w kulturze, red. M. Rudaś-Grodzka i in., Warszawa 2014.

Citati P., Saturn i melancholia, thum. J. Ugniewska, „Odra” 2003, nr 10.

Dąbrowski M., Ponowoczesna melancholia. Modelowanie rozumienia, „Anthropos” 2007, nr 8-9.

Freud S., Żałoba i melancholia, tłum. R. Reszke [w:] idem, Psychologia nieświadomości, Warszawa 2007.

Гундорова T., Femina Melancholica. Cmать і культура в тендерній утопії Ольги Кобилянської, Київ 2002.

Гундорова Т., Ольга Кобилянська contra Ніщче, або Народження жінки з духу природи [w:] Гендер і культура. Збірник статей, упоряд. В. Агеєва, С. Оксамитна, Факт, Київ 2001.

Irigaray L., Ciało w ciało z matka, tłum. A. Araszkiewicz, Kraków 2000.

Kierkegaard S., Albo-albo, t. 2, thum. K. Toeplitz, Warszawa 1982.

Kilbansky R., Panofsky E., Saxl F., Saturn i melancholia. Studia z historii, filozofii, przyrody, medycyny, religii oraz sztuki, tłum. A. Kryczyńska, Kraków 2009.

Кобилянська О., Слова зворушеного серия: Щоденники. Автобіографії. Листи. Статmi ma спогади, упорядн. Ф.П. Погребенник, Дніпро, Київ 1982

Кобилянська О., Царівна [w:] О. Кобилянська, Твори у 5 m., т. 1, Київ 1963.

Кобилянська O., Valse Mélancolique [w:] 3 неприкритою головою. Українська жіноча проза, упоряд. В. Агаєва, Комора, Київ 2013.

Kristeva J., Czarne słońce. Depresja i melancholia, tłum. M.P. Markowski, R. Ryziński, Kraków 2007.

Микосянчик Ю., Театр і музика в житті Ольги Кобилянської, „Буковинський журнал" 1998, nr 1.

Павличко С., Дискурс модернізму в украӥнській літературі, Либідь, Київ 1999.

Павлишин М., Ольга Кобилянська: прочитання, Акта, Харків 2008.

Рибак О., Украӥнский жіночий рух у контексті теоріі соціализму і націоналного відродження (кінец̧ь XIX - початок XX cm.) [w:] Ukraińska myśl polityczna w XX wieku, red. M. Pułaski, Kraków 1993.

Smoleń B., Koncepcja melancholii Julii Kristevej [w:] Sumienie, wina, melancholia. Materiaty polsko-niemieckiego seminarium, red. P. Dybel, Warszawa 1999.

Ткачук М., Творчий портрет Ольги Кобилянської, „Наукові записки. Тернопільський національний педагогічний університет ім. В. Гнатюка. Серія: Літературознавство" 2010, nr 29.

Томчук Л.В., Жіноча меланхолія як текст, „Наукові записки. Національного університету Острозька академія. Серія Філологічна" 2008.

Waga A., Niektóre aspekty intertekstualności w utworach Olgi Kobylańskiej, „Науковий вісник Волинського національного університету імені Лесі Українки” 2009, nr 12. 